\title{
Metal Removal and Antimicrobial Properties of Watermelon rind modified with clove
}

\author{
N. Othman. ${ }^{1, *}$, N. Azhar ${ }^{1}$, Megat Abdul Rani ${ }^{1}$, P. S, and H. Mohamed Zaini ${ }^{1}$ \\ ${ }^{1}$ Micropollutant Research Centre, Faculty of Civil and Environmental Engineering, University Tun \\ Hussein Onn Malaysia.
}

\begin{abstract}
The current rapid development of industrial activity indirectly discharged pollutant into the local water stream. One of the harmful industrial wastes that enter public drainage is heavy metal owing to its toxic, non-biodegradable and persistent in nature. Improper treatment of domestic waste also will discharged high amount of microbial. Various types of technology were developed for removing pollutant in wastewater, but most of the technology employed to address on removing organic content in wastewater. Other pollutant namely, heavy metals and microbial indirectly treated at low concentration of pollutant loading. Among various available technologies for water treatment adsorption process is considered a promising technology as compared to other methods because of convenience, easy operational and low cost of treatment. The aim of this study is to investigate potential used of local fruit rind modified with herb as adsorbent material. The rind present strong potential due to its high content of cellulose, pectin, hemicellulose and lignin as active binding sites for metal sorption. Modified rind improves absorption by having anti microbial properties to kill pathogenic organisms. The concentration of heavy metal ions was analysed using ICP-MS. E. coli and total colifrm were plated out using chromocult agar. The results showed significant reductions of heavy metals and microbial concentration after wastewater was treated with clove modified rind.
\end{abstract}

\section{Introduction}

Wastewater contains several types of contaminants that indicate its quality. The quality of wastewater depends on level of $\mathrm{pH}$, biodegradable and non degradable organics, inorganic, pathogens and nutrients. Left untreated, these contaminants would enter our waterways excessively, affecting the source of water for consumption and fisheries and reducing the recreational value of the waterways as well.

Inorganic minerals, metals and compounds are common in wastewater from residential and non-residential sources. The inorganics such as sodium, potassium, calcium, magnesium, cadmium, copper, lead, nickel, zinc and mercury have originated from industrial or commercial sources and runoff water [1]. Inorganics are stable, persistent and

* Corresponding author: norzila@uthm.edu.my 
non degradable. The inorganic produce effects to aquatic living things and the environment as well. Thus wastewater treatments to remove the inorganic are very important to reduce the risk of harmful caused by inorganic activities.

Greywater and blackwater from typical homes contain enough pathogens to pose a risk to public health. Other likely sources in communities include hospitals, schools, farms, and food processing plants. Some illnesses from wastewater-related sources are relatively common. Gastroentritis can result from varieties of phatogens and other important wastewater-related diseases include Hepatitis A, thypoid, polio, cholera and dysentery [2].

Currently, a number of methodologies with varying degrees of success have been developed to manage water pollution. Some of them involve chemical precipitation, chemical coagulation, ion-exchange, solvent extraction electrochemical, adsorption using activated carbon, biosorption and membrane filtration [3]. However, several of these methods have their own shortcomings and limitations. Among various available technologies for water pollution, adsorption process is considered a promising technology as compared to other methods because of convenience, easy operation and low cost of treatment [4].

Several suitable agricultural by-products which contain lignocellulosics have been investigated as adsorbent material for removal of heavy metals from contaminated aqueous systems [5]. Naturally, herbs contain active compound such as eugenol, carvacrol, linalol and carsonic acid that have been identified as antimicrobial activity by a degradation cell wall or disruption of cytoplasmic membrane [6]. The objective of this study is to investigate heavy metal removal and antibacterial properties from watermelon rind modified with herb.

\section{Materials and method}

\subsection{Sampling of wastewater.}

The wastewater was sampled using grab sampling. The samples were collected over dry weather and in the morning for ensuring peak flow. The sample was collected and stored in a clean bottle and kept in a box with ice. The sample was stored in a refrigerator at approximately $4^{\circ} \mathrm{C}$.

\subsection{Preparation of biosorbent.}

The watermelon rind was collected from the local fruit stall and washed with tap water. The rind was dried in sunlight until dry. The biosorbent was then soaked in nitric acid $\left(\mathrm{HNO}_{3}\right)$ with concentration of $5 \%$ for 24 hours for removing metals and transferred to deionized water $\left(\mathrm{H}_{2} \mathrm{O}\right)$ for 24 hours. The rind was then washed with $60^{\circ} \mathrm{C}$ hot water several times to ensure $\mathrm{pH}$ in the range of $6.5-7.5$. The rind was dried in an oven at $60^{\circ} \mathrm{C}$ until constant dry.

\subsection{Preparation of herb.}

The herb used in this study was clove. It was soaked in deionized water for 24 hours and air dry until reach constant weight. Dried herbs were grinded. Three different weights of herbs were placed in a round bottom flask. About $50 \mathrm{ml}$ of water was added for distillation purpose. After distillation the sample was concentrated using a rotary evaporator. 


\subsection{Preparation of rind with clove extract}

The dried rind was boiled with clove extract. The prepared rind with the herb was air dried and was pulverized, using laboratory ball mill $150 \mu \mathrm{m}$ particle sizes.

\subsection{Design Experiment}

All experiments were conducted using the batch method of varying mass of modified watermelon rind into three different masses namely, $3 \mathrm{~g}, 5 \mathrm{~g}$ and $7 \mathrm{~g} .100 \mathrm{~mL}$ of wastewater was mixed with the modified biosorbent and the mixture was shaked at $125 \mathrm{rpm}$ at room temperature in aerobic condition for 24 hours. The mixture was then filtered. The biosorbent was analysed using XRF, SEM-EDX and FTIR. The wastewater was analysed using ICP-MS. E. Cole and total coliform were checked through out the study.

\section{Results and Discussion}

\subsection{Characterization of metals in domestic wastewater}

The results from ICP-MS show that zinc $(\mathrm{Zn})$, ferum $(\mathrm{Fe})$ and lead $(\mathrm{Pb})$ were found in the domestic wastewater. Table 1 shows heavy metal concentration.

Table 1. Concentration range of heavy metals.

\begin{tabular}{|c|c|}
\hline Heavy Metals & Concentration (mg/L) \\
\hline Zinc $(\mathrm{Zn})$ & $1.50-2.50$ \\
\hline Ferum $(\mathrm{Fe})$ & $0.90-0.85$ \\
\hline Lead $(\mathrm{Pb})$ & $0.09-0.08$ \\
\hline
\end{tabular}

The results show that certain concentrations of heavy metals present in significant concentration. Even, in low concentration heavy metals can cause severe effects to human health and the environment due to non-degradable and persistent [5].

\subsection{XRF Analysis.}

The result from XRF before and after the biosorption is shown in Table 2. Concentration of silica oxide $\left(\mathrm{SiO}_{2}\right)$ was $78.80 \%$. The highest value of silica compares to other chemical compound is triggering the capability of watermelon rind in metal adsorption. The results also show that loaded of $\mathrm{Zn}, \mathrm{Fe}, \mathrm{Pb}$ is $24.40 \%, 1.34 \%$ and $0.05 \%$ respectively after biosorption. These results indicate the capability of modified fruit rind to adsorb metals, namely $\mathrm{Zn}, \mathrm{Fe}$ and $\mathrm{Pb}$. The presents of a very high silica content in the watermelon rind as a precursor for metal removal [1]. This is due to the capability of silica in ion exchange process over metals removal. 
Table 2. Result of XRF before and after biosorption.

\begin{tabular}{|c|c|c|}
\hline Formula & $\begin{array}{c}\text { Concentration } \\
\text { before }\end{array}$ & $\begin{array}{c}\text { Concentration } \\
\text { After }\end{array}$ \\
\hline ori-g & 7 & 7 \\
\hline added-g & 3 & 3 \\
\hline $\mathrm{CO}_{2}$ & $0.10 \%$ & 0.1 \\
\hline $\mathrm{SiO}_{2}$ & $78.80 \%$ & $1.18 \%$ \\
\hline $\mathrm{SO}_{3}$ & $8.32 \%$ & $0.93 \%$ \\
\hline $\mathrm{CaO}_{2}$ & $2.18 \%$ & $0.15 \%$ \\
\hline $\mathrm{Al}_{2} \mathrm{O}_{3}$ & $1.61 \%$ & $0.26 \%$ \\
\hline $\mathrm{Fe}_{2} \mathrm{O}_{3}$ & $1.00 \%$ & $1.34 \%$ \\
\hline $\mathrm{P}_{2} \mathrm{O}_{5}$ & $0.99 \%$ & $0<\mathrm{LLD}$ \\
\hline $\mathrm{K}_{2} \mathrm{O}$ & $0.87 \%$ & $\mathrm{ND}$ \\
\hline $\mathrm{Cl}$ & $0.82 \%$ & $\mathrm{ND}$ \\
\hline $\mathrm{MoO}$ & $0.30 \%$ & $\mathrm{ND}$ \\
\hline $\mathrm{ZnO}$ & $\mathrm{ND}$ & $24.40 \%$ \\
\hline $\mathrm{PbO}$ & $\mathrm{ND}$ & $0.05 \%$ \\
\hline
\end{tabular}

\subsection{SEM-EDX Analysis.}

SEM-EDX analyses that are presented in this paper are based on the results using watermelon rind as biosorbent in removing specific target heavy metals. Figure 1 shows native biosorbent. The figure shows that watermelon rind gave a porous surface texture which enables the adsorption of metal ions onto the surface. Besides, it also shows that the surface morphology of watermelon rind consisted of two kinds of regions which were lighter and darker [7]. The lighter shades represented inorganic component, while the darker shades were organic components. Silica is present in the spectrum as shown in Figure. 1 and 2. It is triggered the capability of watermelon rind in removing metals. This result agrees with XRF result in the appearance of silica oxide in certain concentrations. The morphology of watermelon rind underwent a physical change after biosorption metal ions. Lump-like deposits or shiny particle indicated the presence of metal ions as the light spotted in that area (Figure 2). 


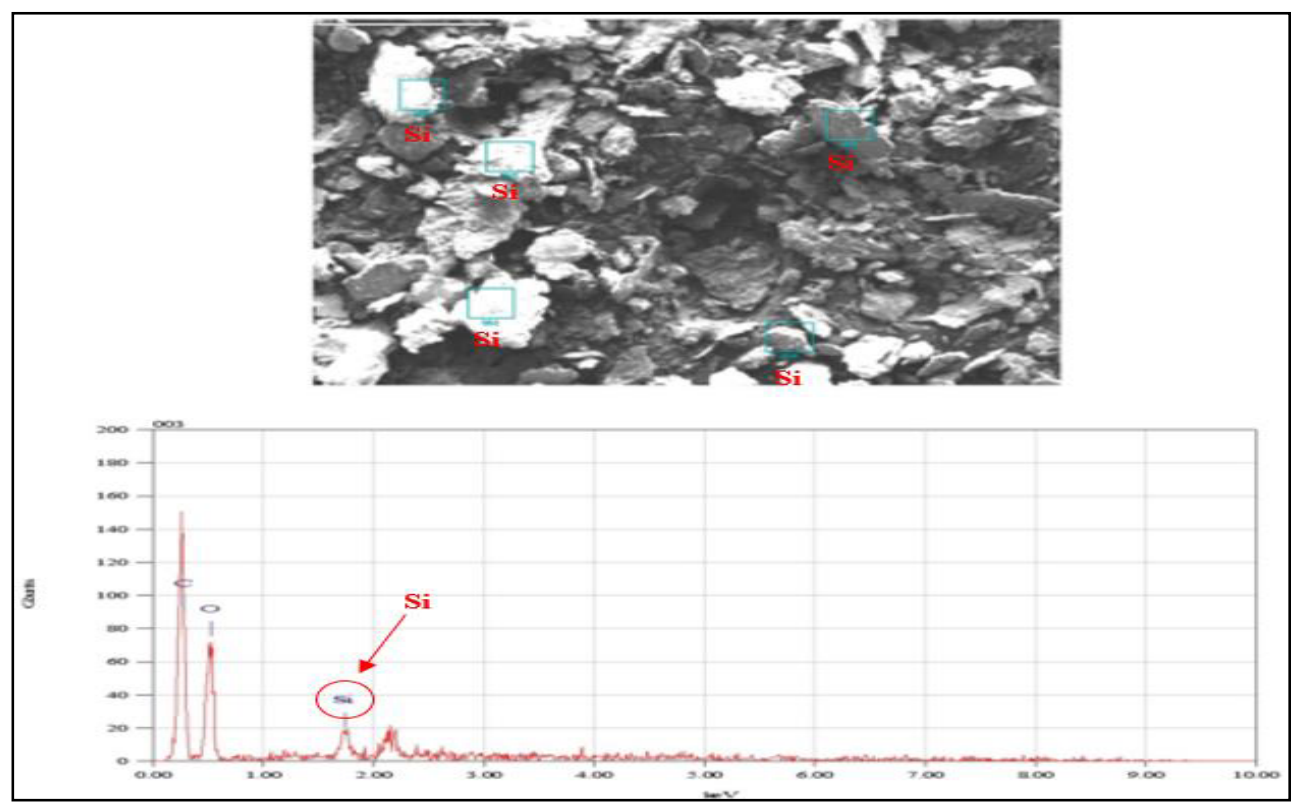

Fig. 1. SEM-EDX before biosorption.

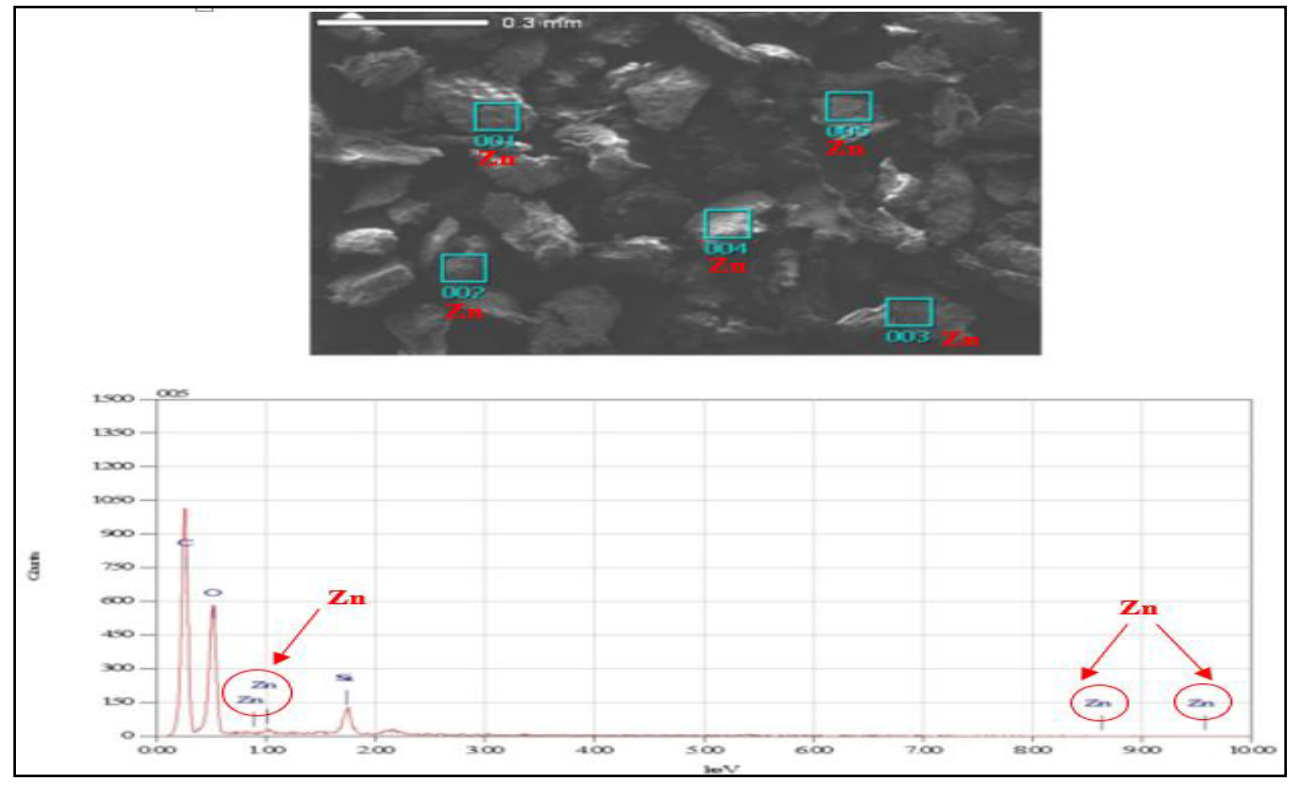

Fig. 2. SEM-EDX after biosorption.

\subsection{FTIR Analysis}

The characteristic band region at $1017 \mathrm{~cm}^{-1}$ to $1028 \mathrm{~cm}^{-1}$ suggests the presence of alcohol group; while alkene group present in band region at $1607 \mathrm{~cm}^{-1}$ to $1622 \mathrm{~cm}^{-1}$ as shown in Table 3. Both alcohol and alkene stretching show major shifting of the peak with more than $10 \mathrm{~cm}^{-1}$ that confirmed the function of both groups in helping heavy metal and microbial 
removal. The appearance of specific functional groups in this study is well agreed with previous studies by Ahmad et al [1] but the number of wavelengths shifted vary according to the type of adsorbent and media. The appearance of alcohol group shows potential of modified watermelon rind as antibacterial and high capability in removing E. coli and total coliform.

Table 3. FTIR Analysis of watermelon after modifying with herb.

\begin{tabular}{|c|c|c|l|}
\hline \multicolumn{2}{|c|}{ Wavenumber $\left(\mathbf{c m}^{-1}\right)$} & \multirow{2}{*}{$\begin{array}{c}\text { Identified } \\
\text { Wroups }\end{array}$} & \multicolumn{1}{c|}{ Remarks } \\
\hline 1017.81 & 1028.42 & $\mathrm{C}-\mathrm{O}$ & $\begin{array}{l}\text { Alcohol groups responsible for } \\
\text { watermelon }+ \text { clove- major shift of wave } \\
\text { number } \geq 10 \mathrm{~cm}-1\end{array}$ \\
\hline 1607.45 & 1622.84 & $\mathrm{C}=\mathrm{C}$ & $\begin{array}{l}\text { Alkene groups responsible for } \\
\text { watermelon }+ \text { clove- major shift of wave } \\
\text { number } \geq 10 \mathrm{~cm}-1\end{array}$ \\
\hline
\end{tabular}

\subsection{Biosorption}

The data from Table 4 revealed that maximum removal of heavy metals can be achieved up to $80 \%, 77 \%$ and $67 \%$ for zinc, ferum and lead respectively in the actual domestic wastewater.

Table 4. Concentration of metals before and after treatment with modified watermelon rind.

\begin{tabular}{|c|c|c|}
\hline Heavy Metals & $\begin{array}{c}\text { Concentration } \\
\text { before treatment } \\
(\mathbf{m g} / \mathbf{L})\end{array}$ & $\begin{array}{c}\text { Concentration } \\
\text { before treatment } \\
(\mathbf{m g} / \mathbf{L})\end{array}$ \\
\hline Zinc $(\mathrm{Zn})$ & $1.50-2.50$ & $0.30-0.36$ \\
\hline Ferum $(\mathrm{Fe})$ & $0.90-0.85$ & $0.20-0.35$ \\
\hline Lead $(\mathrm{Pb})$ & $0.09-0.08$ & $0.03-0.04$ \\
\hline
\end{tabular}

The maximum removal refers to the state where the metal bindings reach their equilibrium state. In this condition, the treatment became stable and further adsorption could not take place because the surface area has reached the saturation point [8-10]. Nevertheless, percentage removal also depends on concentration of heavy metal and other pollutant that present in the wastewater sample and also type of media being used in the study. It is proven by previous studies on using other biosorbent such as durian peel [11] and banana peel [12]

\subsection{E. coli and Total coliform}

The removal of both $E$. coli and total coliform increases as mass of modified watermelon rind increases. Othman [13] also revealed that mass of adsorbent among factors that affecting biosorbent. After treating with $7 \mathrm{~g}$ modified watermelon rind both $E$. coli and total coliform are not detected. This is due to the presence of the active compound in alcohol group that have been identified as antimicrobial activity by a degradation cell wall or disruption of cytoplasmic membrane [6]. This result in line with the FTIR spectrum 
analysis that proved the appearance of alcoholic group in the clove extract that assisted as antimicrobial properties. Both results confirm the performance of clove modified watermelon rind in removing E. coli and total coliform from wastewater. Both E.coli and total microbial are important microbial need to be removed due to the detrimental effect towards health and normally ingested through foot exposed to polluted water. The results also show that both E.coli and total colifm treated with clove modified watermelon rind resulted to save level of water sample below than the standard, Interim National Water Quality Standard (INWQS).

Table 4. E. coli and Total coliform before and after treatment with modified watermelon rind

\begin{tabular}{|c|c|c|c|c|c|}
\hline $\begin{array}{c}\text { Mass } \\
\text { herbs } \\
\text { (g) }\end{array}$ & $\begin{array}{c}\text { Before } \\
\text { treatment } \\
\left(x 1^{6}\right)\end{array}$ & $\begin{array}{c}\text { Total } \\
\text { coliform } \\
\text { after } \\
\text { treatment }\end{array}$ & $\begin{array}{c}\text { E.coli after } \\
\text { treatment }\end{array}$ & $\begin{array}{c}\text { INWQS } \\
\text { Total } \\
\text { coliform } \\
\text { (Standard) }\end{array}$ & $\begin{array}{c}\text { INWQS } \\
\text { E.coli } \\
\text { (Standard) }\end{array}$ \\
\hline 5 & $\begin{array}{l}\text { total coliform } \\
=89 \\
\text { E.coli } \\
=68\end{array}$ & $\begin{array}{l}3 \mathrm{gm} \text { rind } \\
=10 \times 10^{2} \\
5 \mathrm{gm} \text { rind } \\
=2 \times 10^{2} \\
7 \mathrm{gm} \text { rind } \\
=3 \times 10\end{array}$ & $\begin{array}{l}3 \mathrm{gm} \text { rind } \\
=2 \times 10^{2} \\
5 \mathrm{gm} \text { rind } \\
=4 \times 10 \\
7 \mathrm{gm} \text { rind } \\
=\mathrm{ND}\end{array}$ & $50 \times 10^{3}$ & $5 \times 10^{3}$ \\
\hline 7 & $\begin{array}{l}\text { total coliform } \\
=89\end{array}$ & $\begin{array}{l}3 \mathrm{gm} \text { rind } \\
=\mathrm{ND} \\
5 \mathrm{gm} \text { rind } \\
=\mathrm{ND} \\
7 \mathrm{gm} \text { rind } \\
=\mathrm{ND}\end{array}$ & $\begin{array}{l}3 \mathrm{gm} \text { rind } \\
=\mathrm{ND} \\
5 \mathrm{gm} \text { rind } \\
=\mathrm{ND} \\
7 \mathrm{gm} \text { rind } \\
=\mathrm{ND}\end{array}$ & $50 \times 10^{3}$ & $5 \times 10^{3}$ \\
\hline 8 & $\begin{array}{l}\text { E.coli } \\
=68\end{array}$ & $\begin{array}{l}3 \mathrm{gm} \text { rind } \\
=\mathrm{ND} \\
5 \mathrm{gm} \text { rind } \\
=\mathrm{ND} \\
7 \mathrm{gm} \text { rind } \\
=\mathrm{ND}\end{array}$ & $\begin{array}{l}3 \mathrm{gm} \text { rind } \\
=\mathrm{ND} \\
5 \mathrm{gm} \text { rind } \\
=\mathrm{ND} \\
7 \mathrm{gm} \text { rind } \\
=\mathrm{ND}\end{array}$ & $50 \times 10^{3}$ & $5 \times 10^{3}$ \\
\hline
\end{tabular}

\section{Conclusion}

The watermelon rind modified with herb show high capability in removing metals such as zinc, ferum and lead in domestic wastewater. It is also shown antibacterial properties by reducing $E$. coli and total coliform.

This research was funded by UTHM under Centre of Research and Commercialization.

\section{References}

1. M. A. Ahmad, R. Alrozi, Chem. Eng. J., 165, 883 (2012)

2. M. Bilal, J.A. Shah, T. Ashfaq, S.M.H. Gardazi, A.A. Tahir, A. Pervez, Q. Mahmood, J. Hazard Mater., 263, 322 (2013) 
3. A.K. Minocha, Indian J. Chem. Techn., 13(3), 203 (2006)

4. M. Nikazar, N. Afshari, Afinidad, 62(518), 326 (2005)

5. N. Othman, S. Mohd Asharudin, Adv. Mat. Res., 93, 266 (2013)

6. S. Sethi, S. Dutta, B. Gupta, B.S. Gupta, International Journal of Pharmacy and Pharmaceutical, 55, 260 (2012)

7. N. Othman, A.S. Che Azhar, A. Suhaimi, Appl. Mech. Mater.,680, 150 (2014)

8. N. Othman, F.H. Azizul Rahman, Appl Mech Mater, 680, 146(2014)

9. A. Abdul Kadir, N.M. Azmi, International journal of sustainable construction, 3(2) 70 (2012)

10. R.M. Mohamed, A.H.Kassim, Journal of sustainable development, 9(1), 35 (2014)

11. W.W. Wong, F.M.A. Liong, M.E. Azhar, Food Res. Int., 15(3), 363 (2008)

12. P. Kaewsarn, W. Saikaew, S. Wongcharee, Dried biosorbent derived from Banana peel : A potential biosorbent for removal of cadmium ions from aqueous solution (The 18h Thailand Chemical Engineering and Applied Chemistry Conference October 20-2 2008, Pattaya, Thailand. 2008)

13. N. Othman, S. Mohd-Asharudin, Appl. Mech. Mater., 389, 29 (2011) 